\title{
Content and layout development and validation of a vocal health guide for older adults
}

\author{
Marcela Leiros Maciel Macedo ${ }^{1}$ \\ https://orcid.org/0000-0002-4991-2225 \\ Simone Pereira Lins Chaves ${ }^{1}$ \\ https://orcid.org/0000-0002-1959-3462 \\ Ana Karênina de Freitas Jordão do Amaral ${ }^{1}$ \\ https://orcid.org/0000-0002-7470-7717 \\ Émerson Soares Pontes ${ }^{1}$ \\ https://orcid.org/0000-0002-8455-016X \\ Danielle do Nascimento Silva ${ }^{1}$ \\ https://orcid.org/0000-0001-6019-014X \\ Raphaela de Lima Cruz ${ }^{1}$ \\ https://orcid.org/0000-0003-1240-1111 \\ Nathalia Cavalcanti Ribeiro de Souza ${ }^{1}$ \\ https://orcid.org/0000-0002-7318-2146
}

1 Universidade Federal da Paraíba - UFPB, João Pessoa, Paraíba, Brasil.

Conflict of interests: Nonexistent

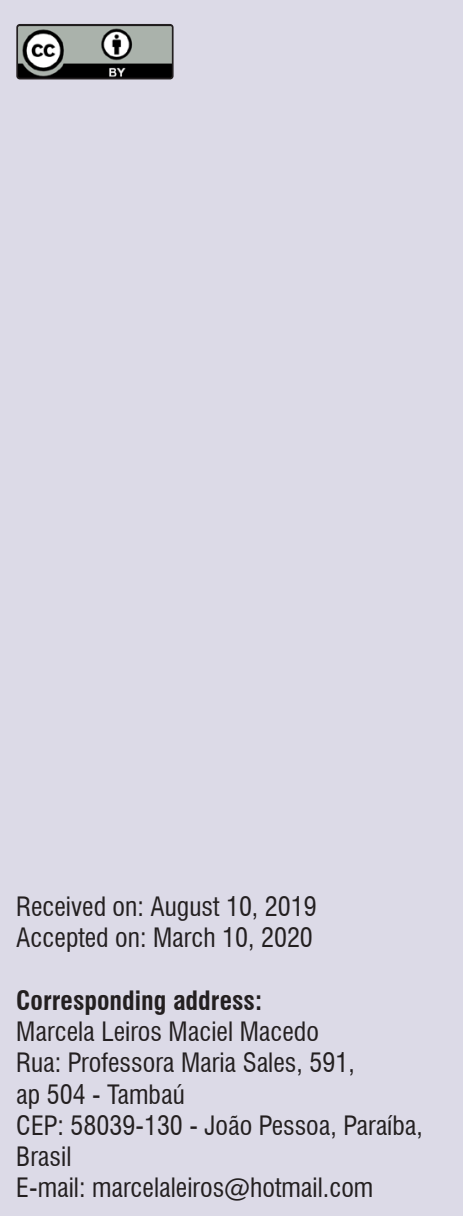

\section{ABSTRACT}

Purpose: to develop and validate the content and layout of an educational guide on promoting vocal health of older adults.

Methods: a methodological study, conducted in two stages: 1 - Development of the guide as an educative technology; 2 - Qualification of the educative material with validation of the guide's content, layout and suitability by 13 judges (speech-languagehearing pathologists) and legitimization of the educative material by the target population, 9 older adults. The validation of the guide by the judges and older adults was based on the content validity index.

Results: the aspects of objectivity, structure, presentation and relevance of the content were considered pertinent by the judges with an approximate score average of 0.92 . However, some words were substituted or removed to bring more clarity to the reader, without loss to the overall message, in addition to the suggestions that were accepted for the final version. The older adults returned a positive assessment.

Conclusion: the educative guide was validated regarding the aspects of content, layout and suitability for the vocal health promotion of older adults. Their knowledge of voice health is expected to promote the quality of life and benefit active and healthy aging.

Keywords: Aged; Voice; Teaching Material; Speech, Language and Hearing Sciences; Health Promotion 


\section{INTRODUCTION}

Vocal well-being and health are important components in promoting a better quality of life and preventing risks of vocal alterations in the population of older adults $^{1,2}$. Such aspects can help improve communication through the health promotion approach focused on taking care of the voice ${ }^{3}$.

Through instructions and information, the individual can learn, understand and identify the practical aspects of the vocal habits. These habits can be applied in daily life, as it is understood that more care with the voice leads to a clearer, cleaner and more pleasant voice to the listener ${ }^{1}$. Maintaining vocal health is essential so that vocal disorders will not interfere with the teachinglearning process ${ }^{3}$.

As the quality of life of older adults progresses, the process of populational aging occurs at a fast pace. The World Health Organization (WHO, 2015) recommends deep changes to be made in the health services and policies related to elderly people, so they can enjoy this phase of life as much and as healthy as possible. Active aging is much more than the absence of diseases; it means maintaining the functional capacity the individual still has ${ }^{4,5}$.

In human aging, biological and physiological changes take place in the body, as well as in its functions ${ }^{6}$. Voice aging, known as presbyphonia, is a natural process; however, accompanied by inadequacies in voice health, communication can become more difficult ${ }^{7}$. In this sense, the importance of delaying or diminishing such impact is highlighted, which can be achieved through daily actions and practices, as physical exercises (sports activities), water intake, healthy eating habits, effort to achieve a soft speech with no tension in the voice, free from vocal abuse ${ }^{1}$.

Based on these premises, the speech-languagehearing pathologist, who works directly on the promotion of health, can make use of an educative material that sustains strategies and knowledge for a better vocal quality in the older adults. In the format of a guide, this material directly influences health education, which has an essential role in the teachinglearning process. Thus, it contributes to the knowledge and perception of voice use in older adults, besides promoting autonomy, daily decision-making, and empowering this population to take care of their own health ${ }^{8}$.

Therefore, it is believed that an educative guide targeting the elderly population, with specific purposes and reflexive approaches, can complement the continuous education and favor the acquisition and adaptation of new knowledge in the care of vocal health included in the routine of older adults. Hence, this study aimed at developing and validating the content and layout of an educative guide intended to promote vocal health in older adults. The guide presents strategies, reflections and instructions towards the older adults' vocal health promotion, through basic information related to caring for their own voice.

\section{METHODS}

This research was submitted to and approved by the Research Ethics Committee of the Universidade Federal da Paraíba (UFPB), PB, Brazil, in compliance with the Resolution 510/2016 of the Conselho Nacional de Saúde (Brazilian National Health Council) and approved under evaluation report no. 2.190.153.

It is characterized as a methodological study with a quantitative/qualitative approach. The research aimed at developing and validating an educative technology (guide) about vocal aging, whose target population is the older adult, having in mind the strategy of health promotion in the elderly people, highlighting the self-care with their voice ${ }^{9}$.

The study was composed of two stages, the first of them being the development of the educative material and editing of the guide itself. The second stage was the qualification of the educative material with validation of the content, layout and guide suitability, by specialized judges, and legitimation of the educative material by the target population, i.e., the older adults ${ }^{10,11}$.

\section{Development of the Educative Guide}

The first stage consisted of the technical-scientific development of the guide, whose title is "From voice to aging". The content encompasses the initial presentation, an invitation to reading and then the index, with the following subjects presented as items: in item 1, "Would you like to know how your voice is produced?" - a brief account of how the voice is produced, with a reflection for the older adult regarding their own voice perception; item 2, "Vocal well-being: 2.1 - Water intake (benefits of water intake, tips on flavored water for the older adults who do not like to drink water, and a reflection on the importance of the amount of daily water intake and vocal health); 2.2 - Eating habits (tips on healthy eating, explanation of what gastroesophageal reflux is, its signs and symptoms, and a reflection on healthy eating); 2.3 - Body and voice (relationship 
of the body and its movements with the voice); 2.4 Breathing (information on breathing and its support to voice, with some physical exercises, besides a tip on care); 2.5 - Actions to articulate words well and open the mouth wide enough (instructions on the benefit of articulating better); 2.6 - Speaking without effort (seeking effortless communication); 2.7 - Singing in a choir (the benefits of singing for older adults); 2.8 Self-medication (being careful with large amounts of medication, along with a reflection on being cautious about taking medications without medical prescriptions, as well as making use of homemade formulas); 2.9 - Smoking (information on how smoking is related to the voice); 2.10 - Difficulties in hearing (making adults aware about the relationship between speaking too loud and their own hearing)".

The guide contains information, instructions and illustrations to make the reader's understanding easier. The images' design and layout were worked on by professionals in the specific field of communication and advertisement.

\section{Validation of the educative material}

The second stage of the study counted with the qualification of the educative material by means of validating - through the judges' assessment and then the target population's - its content and layout and, posteriorly, its suitability. The concept of content and layout validity used in this investigation is the one proposed by Polit and Beck ${ }^{9}$.

A judging instrument was developed to assess the guide's content and layout, which evaluated the product's objective, structure, presentation and relevance ${ }^{10}$. The analysis was composed of each item's agreement and relevance correspondence to a Likert-type scale ${ }^{11}$.

The Likert scale is a method very often applied in the field of health. It is a type of psychometric response scale, which measures the proportion of judges who agree on a certain aspect of the instrument, informing with a statement their level of agreement. In the scale, the answer that best reflects their opinion must be marked, considering: 1) I totally disagree; 2) I disagree; 3) I am indifferent (or neutral); 4) I agree; 5) I totally agree. Commonly used in questionnaires, the number of points in the scale can range from 4 to 10 items $^{9,12}$.

In the validation process, 11 content specialists were contacted (experienced researchers or professors in the field of voice and/or public health); of these, seven decided to participate. As for the technical judges (speech-language-hearing pathologists with clinical practice with older adults and experience in health promotion and/or voice and/or aging), seven were invited, six of whom participated in the research. The judges were sought by convenience, indicated by specialists in the field. Thus, 13 specialists were identified, who signed the Informed Consent Form (ICF). Data collection took place in January 2018. The judges were e-mailed a formal invitation, the ICF, the educative guide, and the assessing instrument for them to fill out.

The 13 speech-language-hearing judges agreed to participate in the research and returned the assessing instrument filled out. The professional profile indicated that three had a doctor's degree (in voice and public health), four had a master's degree, and six were specialists. Five of these people worked as professors (on voice and public health), and six, as assistants (voice/older adults/public health), having worked in their field for an average of two to four years, in the case of two specialists, and from five to 20 years, in the case of the other 11 judges.

Once the instruments were returned, the data obtained were compiled in Excel $^{\circledR}$ spreadsheets. For the statistical analysis, the content validity index used recommended the evaluators a CVI above 0.78 . Hence, the items that obtained a CVI above 0.78, were considered acceptable; those with CVI between 0.78 and 0.66 were changed; and, those below 0.66 were excluded. In this method, the Likert-type scale is employed, with scores ranging from one to four ${ }^{11}$. The index was calculated by adding the agreement of the items marked " 3 " and " 4 " by the judges, then dividing the sum by the total answers.

The formula for the calculation was:

$$
C V I=\frac{\text { Number of " } 3 \text { " or " } 4 \text { " answers }}{\text { Total number of answers }}
$$

After the judges' assessment, the target population assessed the material. Nine older adults were submitted to the mini-mental state examination, to discard any possible cognitive alteration. Then, they were given the assessing instrument along with the printed guide. These older adults were asked to handle the guide and analyze its text and images. The instrument contains the basic data to outline the older adults' profile, besides the answer options regarding the degree of agreement in the Likert scale, for the content, information, knowledge, illustrations, sensitivity and 
motivation criteria. One open-ended question was left for possible comments.

The target population's analysis was considered equal to that of the judges. For the analysis of the openended question, the content analysis method proposed by Bardin ${ }^{12}$ was used. The older adults who participated in the research ranged from 60 (minimum) to 73 years old (maximum), the mean age being 67. Most of them were females $(77.7 \%)$, married $(66.6 \%)$ and with more than 10 years of schooling (88.8\%).

The assessing instrument was composed of objective, structure and presentation, and relevance. The objective referred to the purposes, goals and the like which are intended to achieve with the guide. It assessed the coherence and contribution to bring about changes in the older adults, as well as its suitability to circulate in the scientific context. The structure and presentation dealt with the form of presenting the instructions in the guide, the general organization, structure, presentation strategies, coherence and formatting. The relevance assessed the characteristics of the degree of significance of the educative material presented, whether it leads the older adult to acquire knowledge, whether it approaches issues necessary to health promotion, and whether it was adequate to be used as a technology for the promotion of vocal health in older adults. The instrument also had data of the participants and an open-ended question for them to offer suggestions. After the content judges and technical fudges had assessed, the suggestions were accepted and incorporated into the guide.
When the judges had finished their analysis, the final version of the guide was submitted to the researchers to be revised, so adjustments in the text and images could be made.

\section{RESULTS}

In the development of the guide, it was sought to use adequate language, as in the patients' daily use, which would lead them to reflect. The physiology of vocal aging was highlighted, followed by the importance of vocal health for healthy and active aging, and the effectiveness of actions that can aid in impacting vocal aging.

The educative material presented a simple language, using images for better communication with the reader, in order to make the message easier to be understood and minimize communication barriers. It was characterized as a more efficient technology, with wider reach into its target population, striving to be inviting, easily read and understood.

The aspects of the guide's content's objectivity, structure, presentation and relevance were deemed pertinent by the judges, with an approximate mean of 0.92 , as seen in the tables: Table 1 , with 0.92 ; Table 2 , with 0.94; Table 3, with 0.92. Some words were substituted or removed, to make the text clearer to the reader, without loss to the overall message, in addition to the suggestions that were accepted for the final version. The older adults returned a positive assessment.

Table 1. Assessment conducted by specialized judges and content technicians, regarding the objective of the educative guide on vocal self-care of older adults. João Pessoa- Paraíba- Brazil, 2018

\begin{tabular}{|c|c|c|c|c|}
\hline \multicolumn{5}{|c|}{ Specialized judges and content technicians } \\
\hline Objective: & $\begin{array}{l}\text { Partially } \\
\text { adequate }\end{array}$ & Adequate & $\begin{array}{c}\text { Totally } \\
\text { adequate }\end{array}$ & CVI \\
\hline 1.1 It is coherent with the older adults' needs. & 1 & 2 & 10 & 0.92 \\
\hline 1.2 It contributes to changes in behavior and attitudes & 1 & 2 & 10 & 0.92 \\
\hline $\begin{array}{l}1.3 \text { It is apt to circulate in scientific contexts in the field of voice and/ } \\
\text { or public health }\end{array}$ & 1 & 2 & 10 & 0.92 \\
\hline
\end{tabular}

$\mathrm{CVI}=$ Content Validity Index; * Inadequate is not present, as no evaluator considered it this way; *legend: 0 evaluator, 1 evaluator, 2 evaluator, 10 evaluator. Total number of evaluators: 13 
Table 2. Assessment conducted by specialized judges and content technicians, regarding the structure and presentation of the educative guide on vocal self-care of older adults. João Pessoa- Paraíba- Brazil, 2018

\begin{tabular}{|c|c|c|c|c|}
\hline \multicolumn{5}{|c|}{ Specialized judges and content technicians } \\
\hline Structure and presentation & $\begin{array}{l}\text { Partially } \\
\text { adequate }\end{array}$ & Adequate & $\begin{array}{c}\text { Totally } \\
\text { adequate }\end{array}$ & CVI \\
\hline 2.1 The educative material is appropriate for older adults. & 1 & 3 & 9 & 0.92 \\
\hline 2.2 The messages are clearly and objectively presented. & 1 & 2 & 10 & 0.92 \\
\hline 2.3 The information presented is scientifically correct. & 0 & 1 & 12 & 1.0 \\
\hline 2.4 There is a logical sequence in the content proposed. & 0 & 1 & 12 & 1.0 \\
\hline $\begin{array}{l}2.5 \text { The information is well structured in terms of syntactic } \\
\text { agreement and orthography. }\end{array}$ & 0 & 3 & 10 & 1.0 \\
\hline $\begin{array}{l}2.6 \text { The writing style corresponds to the target population's } \\
\text { knowledge level. }\end{array}$ & 3 & 3 & 7 & 0.76 \\
\hline 2.7 The illustrations are expressive, and their amount is sufficient. & 0 & 1 & 12 & 1.0 \\
\hline
\end{tabular}

$\mathrm{CVI}=$ Content Validity Index; * Inadequate is not present, as no evaluator considered it this way; *legend: 0 evaluator, 1 evaluator, 2 evaluators, 3 evaluators, 7 evaluators, 9 evaluators, 10 evaluators, 12 evaluators.

Total number of evaluators: 13

Table 3. Assessment conducted by specialized judges and content technicians, regarding the relevance of the educative guide on vocal self-care of older adults. João Pessoa- Paraíba- Brazil, 2018

\begin{tabular}{lcccc}
\hline \multicolumn{4}{c}{ Specialized judges and content technicians } & \\
\hline Relevance & $\begin{array}{c}\text { Partially } \\
\text { adequate }\end{array}$ & Adequate & $\begin{array}{c}\text { Totally } \\
\text { adequate }\end{array}$ & CVI \\
\hline $\begin{array}{l}\text { 3.1 The material proposes the patient to acquire knowledge on vocal } \\
\text { health in aging. }\end{array}$ & 0 & 0 & 13 & 1.0 \\
$\begin{array}{l}\text { 3.2 The material approaches the issues necessary for health } \\
\text { promotion. }\end{array}$ & 2 & 1 & 10 & 0.84 \\
$\begin{array}{l}3.3 \text { It is adequate to be used as a vocal health promotion technology } \\
\text { in aging. }\end{array}$ & 1 & 1 & 11 & 0.92 \\
\hline
\end{tabular}

* This item is below average; however, the discussion contemplates the considerations. CVI = Content Validity Index; * Inadequate is not present, as no evaluator considered it this way; *legend: 0 evaluator, 1 evaluator, 2 evaluators, 10 evaluators, 11 evaluators, 13 evaluators.

Total number of evaluators: 13

Table 4. Assessment conducted by older adults, regarding the relevance of the educative guide on vocal self-care of older adults. João Pessoa- Paraíba- Brazil, 2018

\begin{tabular}{lcccc}
\hline & $\begin{array}{c}\text { Partially } \\
\text { adequate }\end{array}$ & Adequate & $\begin{array}{c}\text { Totally } \\
\text { adequate }\end{array}$ & CVI \\
\hline $\begin{array}{l}\text { 1. Has the content called your attention? } \\
\text { 2. Is the information clear and understandable? }\end{array}$ & 0 & 1 & 7 & 1.0 \\
3. Have you acquired knowledge of vocal self-care in aging? & 0 & 0 & 8 & 1.0 \\
4. Have the illustrations helped you understand the text? & 0 & 2 & 6 & 1.0 \\
$\begin{array}{l}\text { 5. Does the guide lead to reflecting on vocal health in aging? } \\
\text { 6. Were you motivated to pass on the information presented in the } \\
\text { guide? }\end{array}$ & 0 & 1 & 7 & 1.0 \\
\hline
\end{tabular}

$\mathrm{CVI}=$ Content Validity Index 


\section{DISCUSSION}

The initiative to develop an educative material came up from reflections on the older adults' vocal health, focused on health promotion and the populational growth of those over 60 years old. The guide aimed to communicate in terms of health, helping them to increase knowledge and awareness of the issues, as well as health problems and solutions ${ }^{13}$.

The need to develop an educative guide for older people was reinforced when some studies stated that the educative guide presents goals not only to inform or change attitudes but also to develop skills and encourage decision-making. When effectively produced, it can change the reality of a population. Therefore, its information and expectations must be considered, as well as the target readers' values, knowledge and experience ${ }^{11,13}$.

It was verified that, in the results obtained from the judges' assessments regarding the educative guide's objective, all the items (1.1, 1.2 and 1.3) achieved CVI above 0.78 , thus being considered clear and apt to compose the final guide. Most of the judges classified them as "adequate" and "totally adequate" (Table 1).

The theme of the educative guide invests in vocal health as an approach to promote the older adult's better quality of life. In another study on the promotion of vocal health in older adults, the importance of taking care of the voice was reinforced, along with changes in habits that were acquired after they had access to the information offered in the instructions and workshops aimed at the older adults ${ }^{15}$. The research was divided into two groups: those that were given instructions, and those that were not. It was noted that those who were given instructions managed to change some habits, whereas those who were not given them, vocal instructions were suggested as a vocal well-being strategy ${ }^{14}$.

The assessments on structure and presentation of the educative guide are presented in Table 2, which shows some discrepancies between the opinions of specialists on item 2.6, i.e., "The writing style corresponds to the target population's knowledge level". It had one score below the acceptable $\mathrm{CVI}$ index of 0.78 , which allows changes in the item according to the suggestions offered by the specialists. For this reason, this item was changed, as suggested by the specialists.

The changes suggested referred to the use of the terms "longevity" (page 3), "protagonist" and "incorporate" (page 4), "flavored" (page 9), "cervical region" (page 10), and "empowerment" (page 8). It was alleged that most of the older adults might be unfamiliar with such concepts. Hence, the suggestions were accepted, and the words were respectively replaced with "extend one's life", "author", "add", "with taste", and "region of the neck". As for the word "empowerment", it was removed from the guide without loss to the overall message. Besides these changes, item 2.7 (eating habits) was moved to 2.3, following water intake, for the text to be better organized. The other items (2.1, 2.2, 2.3, 2.4, 2.5 and 2.7) were considered acceptable, as they presented $\mathrm{CVI}$ above 0.78 , so being apt to be included in the educative guide. The judges further suggested that the items related to smoking and difficulties in hearing be included, which was justified by the prevalence of older adults who smoke and have difficulties in hearing, thus interfering with their voice.

Besides the motivational proposal, the guide "From voice to aging" must also consider that the development of the message has to be simple, so that it can be effectively and quickly understood, and the illustrations have to be attractively presented, clearly communicating the objective of the material. The images must draw the attention and interest of readers in different schooling levels ${ }^{13,16,17}$. Therefore, the changes in the guide's writing style took place due to the importance of the written presentation. The text needs to have a vocabulary that is coherent to the target population, as well as inviting, easily read and understood, because rare terms and technical and complex words make it difficult for the reader to understand, interfering with their readability ${ }^{14}$.

Hence, the guide was developed with basic information on how the voice is produced and what can furnish vocal well-being based on one's choices throughout life. In this regard, from the moment one learns, understands and identifies the vocal habits, the care with their voice becomes more understandable and recognized ${ }^{14}$. Another study aimed at older adults whose work is to educate people highlighted the importance of instructing older adults in order to help them develop and become protagonists of their own life. An empowered older adult will remain more active and capable of carrying on their own actions in the world ${ }^{18}$.

Concerning the relevance of the educative guide, as shown in Table 3, items 3.1, 3.2 and 3.3 presented CVI above 0.78 , therefore being considered apt to make part of the final educative guide without any changes. In this analysis, the specialized evaluators called attention to the reflection related to defining health promotion as the approach for the educative guide, to make the reader reflect on the information and understand it. Not 
as an imposing manner of accepting what the guide offers, but as a reflecting process. Health promotion is characterized as "the process of enabling the public to act on the improvement of their own quality of life and health, including broader participation in the control of this process"19.

Such definition emphasizes health with positive values, instead of analyzing the disease, and turns the individual into a participating subject in their population, calling for their protagonism in the actions and struggles they have to cope with ${ }^{18}$. In this perspective, part of the information provided in the guide at the end of each item's explanation was redirected toward health promotion practices as a means of leading the reader to a rereading of their vocal well-being.

As for the target population, the older adults, they worked only on the relevance of the educative guide. They assessed the items 1, 2, 3, 4, 5, and 6 and presented $\mathrm{CVI}$ above 0.78 , considering them apt to be included in the final version of the guide. In the sequence, Figure 1 shows the content analysis conducted by the older adults, and Figure 2 presents an illustrative representation of the final educative guide, as presented to the specialized judges and the older adults.

In less than a century, life expectancy in Brazil jumped from 43 to 73 years $^{20}$. While such a process has been gradual in some countries, it has been accelerated in Brazil, which occupies sixth place in the expected number of older adults over 60 years old by $2050^{21,22}$. Such growth leads to an increase in what is known as biological fragility in this population, which refers to individuals who depend on others, with adverse disease outcomes and health at risk ${ }^{23}$. With an aged population, health care becomes essential to active longevity, as highlighted by the older adults assessed.

Based on the older adults' meaning units and corresponding statements, three analysis categories arose, which were subdivided according to the similarities in the elements of their statements. In the first category (explanatory), the responses were positive and corroborated with health care, specifically vocal health, which is made evident in these older adult's statements: "It helps clarify how to care for our voice to improve it in the aging process". In addition to care, the older adults complemented with this text: "It is easy to read and understand".

The second category was the importance of the guide to the target population. The older adults reported that "the educative material is of great importance for the older adults, which is instructive and aids in promoting voice health in an easy and simple way". Another older adult wrote: "The material presented is very important". The writing must be attractive at the same time it overcomes possible difficulties ${ }^{14}$. It is important to the reader's decision-making, for them to reflect on their role as subjects of their own actions, instead of persuading toward changes in behavior or attitude without a purpose ${ }^{24}$. The older adults' voiceoriented educative material interacts with the speechlanguage-hearing sciences in terms of health education and its interface with subjectivity, in the effort to overcome the educational model based on the organic view of the body and culpability of the subject ${ }^{25}$.

It is understood that, due to the aging process, WHO advocates strategic changes regarding health services and policies toward the older adults ${ }^{5}$. Through health promotion, the subject can analyze themselves as a unique being in their own action, promoting and valuing

\begin{tabular}{|c|l|}
\hline Meaning units & \multicolumn{1}{c|}{ Statements } \\
\hline Explanatory & $\begin{array}{l}\text { "Very good, easy to read and understand. Rich in content" } \\
\text { "The material is very good and easy to understand. Item 2.8 (Eating habits) stands out for its rich } \\
\text { explanation" } \\
\text { "The material helps to clarify the care we should take of our voice to improve it in the whole aging } \\
\text { process..." }\end{array}$ \\
\hline Important & $\begin{array}{l}\text { "It is an educative material of great importance for older adults, as it instructs and helps to maintain the } \\
\text { vocal health in an easy and simple way". } \\
\text { "The material presented is very important". }\end{array}$ \\
\hline Adequate & "Excellent content; very rich". \\
"... It will bring about more benefits to the older adults' life, making them active and healthy".
\end{tabular}

Figure 1. Assessment conducted by older adults of the educative guide on vocal self-care of older adults, according to meaning units and corresponding statements. João Pessoa- Paraíba- Brazil, 2018 

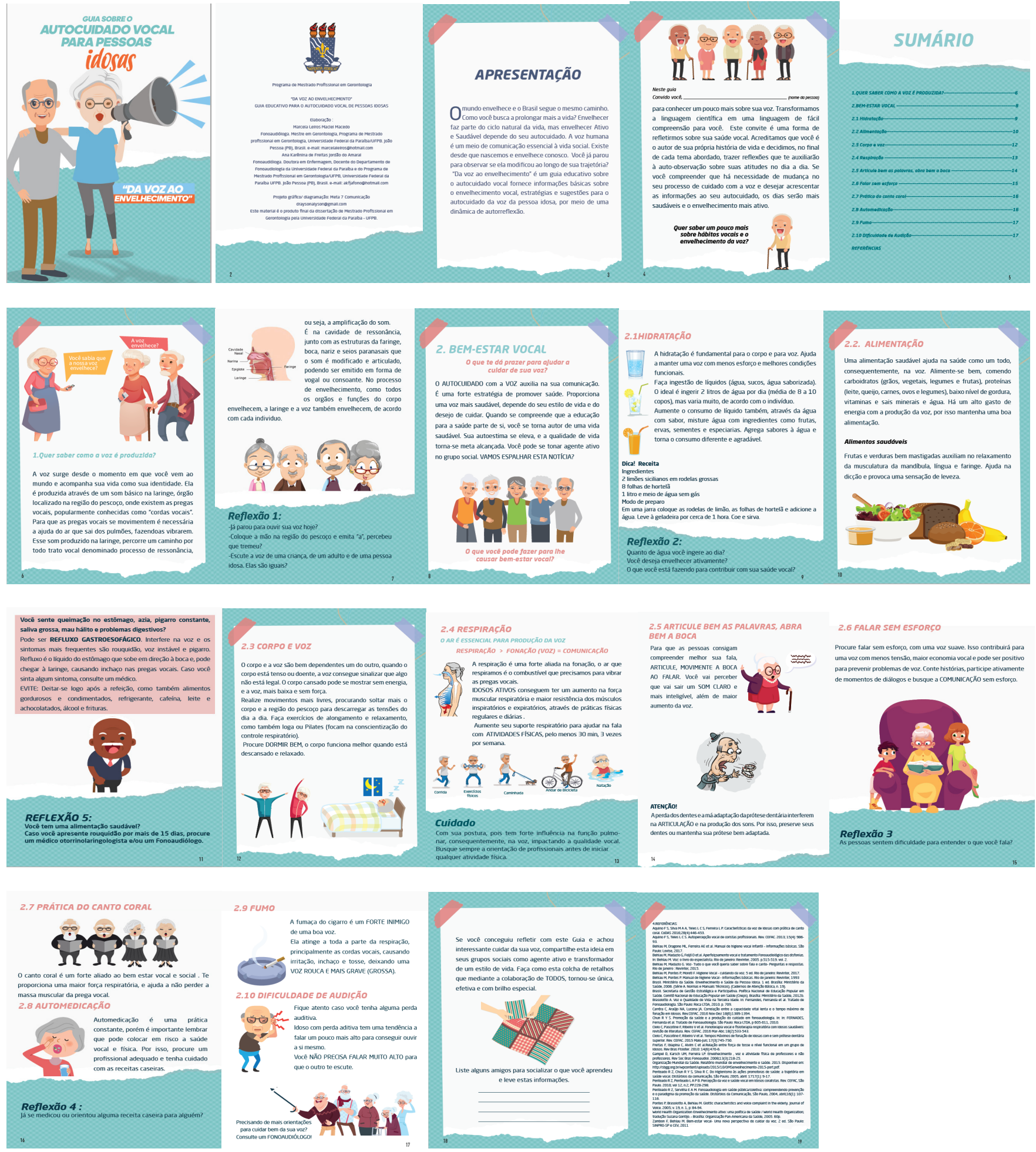

* Sequence of the pages from left to right: cover, presentation, invitation, index. Pages 6 and 7 (1. Would you like to know how the voice is produced? Reflection) Page 8 (2. Vocal well-being). Page 9 (Water intake). Page 10 (Eating habits). Page 11 (Gastroesophageal reflux). Page 12 (Body and voice). Page 13 (Breathing). Page 14. (articulate words well, open your mouth wide enough) Page 15 (Speaking without effort) and 16 (Singing in a choir/Self-medication).

Page 17 (Smoking/Difficulties in hearing). Page 18 (To reflect on), Page 19 (References).

Figure 2. Illustrative representation of the final educative guide on vocal self-care of older adults, as sent to the judges. João Pessoa, Paraíba, Brazil. 2018 
the older adult in their subjectivity as a social being who needs to communicate ${ }^{21}$. As for the third category (adequacy), the older adults commented: "Excellent content, very rich"; "it will bring more benefits to the life of the older adults, making them active and healthy". The older adults' assessment demonstrated that this generation, which is now growing old, is concerned with the cares with their body and communication, and that they continue to seek more knowledge. After the assessment, no changes were necessary.

\section{CONCLUSION}

This study allowed the development and validation of both the content and layout of the guide "From voice to aging" to be concluded. This material is about vocal health promotion for older adults, offering them strategies, reflections and instructions through basic information on vocal self-care.

The purpose of the educative guide was to contribute to a better quality of life to those over 60 years old, aiming at vocal health based on reflections related to their daily life. It should be highlighted that willingness and decisions must come from older adults. Nothing is preestablished, and individuals depend on their observations and reflections to accept - or not the information offered.

It is believed that the guide will contribute to their knowledge on vocal health, influencing towards active and healthy aging. It is important to emphasize the possibility of using the guide in future research as a result of maintaining human beings' functional capacity.

\section{REFERENCES}

1. Behlau M, Pontes P, Moreti F. Higiene Vocal cuidando da voz. 5 ed. Rio de Janeiro: Revinter, 2017.

2. Tariq S, Mumtaz N, Noveen S. Impact of vocal hygiene on self rated vocal health of teachers of pakistan. Int J Rahabil Sci. 2015;4(1):20-4.

3. Lucíola DS, Sayuri TM, Thamara R, Cibele ASA. Atenção à saúde vocal - Aspecto emergente na formação docente. Atas, 2014.

4. Chun RYS. Promoção da saúde e a produção do cuidado em fonoaudiologia. In: Fernandes FDM, Mendes BCA, Navas ALPGP (orgs). Tratado de Fonoaudiologia. 2 ed. São Paulo: Roca. 2010. p.605-11.

5. Organização Mundial da Saúde (OMS). Envelhecimento ativo: uma política de saúde.
Brasília: Organização Panamericana de Saúde; 2005.

6. Costa ML, Fedosse E, Lefevre AP. Doenças crônicas não-transmissíveis - Cuidado em Fonoaudiologia. In: Marchesan IQ, Silva HJ, Tomé MC (orgs). Tratado de Especialidades em Fonoaudiologia. São Paulo: Guanabara Koogan, 2014. p. 810.

7. Brasolotto AG, Wolf $A E$, Diaféria G, Azevedo LL. Voz na senescência e na doença de Parkinson. In: Marchesan IQ, Silva HJ, Tomé MC (orgs). Tratado de Especialidades em Fonoaudiologia. São Paulo: Guanabara Koogan, 2014. p. 171-6.

8. Torres HC, Candido NA, Alexandre LR, Pereira FL. O processo de elaboração de cartilhas para orientação do autocuidado no programa educativo em Diabetes. Rev. bras. enferm. 2009;62(2):312-6.

9. Polit DF, Beck CT. Fundamentos de pesquisa em enfermagem: avaliação de evidências para as práticas da enfermagem. 7. ed. Porto Alegre: Artmed, 2011.

10. Echer IC. Elaboração de manuais de orientação para o cuidado em saúde. Rev. Latino-am Enfermagem. 2005;13(5):754-7.

11. Freitas FV, Rezende Filho LA. Modelos de comunicação e uso de impressos na educação em saúde: uma pesquisa bibliográfica. Interface. 2011;15(36):243-56.

12. Alexandre NMC, Coluci MZO. Validade de conteúdo nos processos de construção e adaptação de instrumentos de medidas. Ciênc. saúde coletiva. 2011;16(7):3061-8.

13. Moreira MF, Nóbrega MML, Silva MIT. Comunicação escrita: contribuição para a elaboração de material educativo em saúde. Rev bras. enferm. 2003;56(2):184-8.

14. Zombini EV, Pelicioni MCF. Estratégias para a avaliação de um material educativo em saúde ocular. Rev Bras Crescimento Desenvolvimento Hum. 2011;21(1):51-8.

15. Bardin L. Análise de conteúdo. Tradução de Luís Antero Neto e Augusto Pinheiro. Lisboa: Edições 70, 2010.

16. Soares EB, Borba DT, Barbosa TK, Medved DM, Montenegro ACA. Hábitos vocais em dois grupos de idosos. Rev. CEFAC. 2007;9(2):221-7.

17. Hoffmann T, Warrall L. Designing effective written health education materials: considerations for health professionals. Disabil Rehabil. 2004;26(9):1166-73.

18. Jones CA, Mawani S, King KM, Allu SO, Smith M, Mohan $S$ et al. Tackling health literacy: adaptation 
of public hypertension educational materials for an Indo-Asian population in Canada. BMC Public Health. 2011;11(24):a.

19. Patrocinio WP, Pereira BPC. Efeitos da educação em saúde sobre atitudes de idosos e sua contribuição para a educação gerontológica. Trab. Educ. Saúde. 2013;11(2):375-94.

20. Instituto Brasileiro de Geografia e Estatística (IBGE). Pesquisa Nacional de Saúde 2013 - Percepção do estado de saúde, estilos de vida e doenças crônicas. Rio de Janeiro: IBGE; 2014.

21. Organização Mundial da Saúde (OMS). Envelhecimento ativo: uma política de saúde. Brasília: Organização Panamericana de Saúde; 2005

22. Instituto Brasileiro de Geografia e Estatística (IBGE). Síntese de Indicadores Sociais - Uma Análise das Condições de Vida da População Brasileira. Rio de Janeiro: IBGE; 2010.

23. Hogan DB, MacKnight C, Bergman H. Steering Committee CloFaA. Models, definitions, and criteria of frailty. Aging Clin Exp Res. 2003;15(3 Supl.):1-29.

24. Araújo I. Materiais educativos e produção de sentidos na intervenção social. In: Monteiro SS, Vargas EP (orgs). Educação, Comunicação e Tecnologia Educacional: interfaces com o campo da saúde. 1ed. Rio de Janeiro: Editora Fiocruz, 2006. p.49-70.

25. Paiva APRC, Vargas EP. Material Educativo e seu público: um panorama a partir da literatura sobre 0 tema. Revista Práxis. 2017;9(18):89-99. 